\title{
Farmer's stance on decreasing production of local red onion (Allium cepa L.) farming in Buttu Pamboang Village, Majene
}

\author{
Maswad', Mir Alam Beddu'2, Ikawati Karim ${ }^{3 *}$, Dwi Ahrisa Putri ${ }^{4}$, and Suyono ${ }^{5}$ \\ 1,3,4,5 Agribusiness Department, Universitas Sulawesi Barat, Indonesia \\ ${ }_{2}^{2}$ Agriculture Faculty, Universitas Islam Makassar, Indonesia \\ *Corresponding author's e-mail: ikawati@unsulbar.ac.id
}

Received January 3rd, 2020; revised January 17th, 2020; accepted February 5th, 2020

\begin{abstract}
In general, farmers in Buttu Pamboang Village in Majene District in carrying out the cultivation of onion plants have not applied the rules of cultivation correctly and precisely, resulting in a decline in crop. Agricultural commodities have a strategic role in realizing government policy to increase foreign exchange acquisition. The toughness of the role in the world trade globalization era is faced with the competition of commodity quality, both in domestic and foreign markets. This Era is characterized by the increasingly free commodity trading between countries in the world including vegetable commodities. In Indonesia, the local red onion plant (Allium cepa L.) has been cultivated by farmers as a commercial farming. However, the presence and demand of red onion that continue to increase every year cannot be followed by the increase in production. Data of the Agricultural office of Pamboang Village, October 2015 that the amount of local red onion productivity ranged from 5-6 tons and the production amount ranged from 10-12 tons with 2 ha of farmland area in 2014. It can be concluded that the production of local red onion in 2015 in the Pamboang Village decreased compared to the previous year, the red onion productivity of 2015 average ranged from 2-3 tons. This research aims to identify the attitude of farmers in Buttu Pamboang Village to decline in production in the onion farming business and know the factors that cause a decline in the production of local red onion in Buttu Pamboang Village in Pamboang District of Majene Regency. To identify the assessment of the farmer's stance, analyzed using Likert scale. The Likert scale is the identification of assessments to measure the attitudes and opinions and perceptions of the person/group on social symptoms. The results of the study proved that the attitude of farmers in Buttu Pamboang Village to the decline of production is good or well received.
\end{abstract}

\section{Keywords:}

Local onion, Production, Farming, Pamboang

\section{Introduction}

The onion plant is one of the many known vegetable commodities in the world, the international call it, red onion [1]. Red Onion can grow and produce well in lowland to high altitude, which is at an altitude of approximately 1,100 meters above sea level. However, the ideal height for optimal production is at a height of $0-800$ meters above the sea level. Onion can produce the best production in the lowlands with a temperature of $25^{\circ} \mathrm{C}-32^{\circ} \mathrm{C}$ and dry climates. Seeds of onion (Allium cepa L.) are reproduced with bulbs. Tuber is taken from a plant that is quite old. Age about 70 days after planting. At that age the growth of prospective shoots in the tuber is full. Tuber should not be too big nor too small. The appearance of tuber should be fresh, healthy, and good shape. Watering is worth noting in the cultivation of onion. During the dry season we need to be able to flush the plants every day since they are planted until one week before the harvest. Watering done morning and afternoon. Since the beginning of planting until the onion plant is 2 weeks old, weed 
grows rapidly thus disrupting the growth of red onion. It is necessary to investigate the action [2].

Local red onion plants require organic fertilizer and inorganic fertilizer. Organic fertilizer given is the manure as much as $10-20$ ton.ha $^{-1}$, given before planting that is when conducting the processing. Organic fertilizer needed is SP36 as much as 150 - $200 \mathrm{~kg} \cdot \mathrm{ha}^{-1}$. This fertilizer is mixed with manure in the application. In addition, we provide additional fertilizer in the form of $300 \mathrm{~kg}$ Urea and $200 \mathrm{~kg}$ KCL.ha-1 ${ }^{-1}$ This fertilizer is given by way of the escape, or the current rows of plants aged 10 - 15 days [3]. Harvest is done by removing the plant. The drying action is necessary to obtain the water content of tuber $80 \%$. Storage room temperature should be $20-30{ }^{\circ} \mathrm{C}$ with the humidity of $60-70 \%$. Varieties of shallots include: Bima Brebes, Medan, Maja Cipanas, Kelling, Ampenan, SUMENEP, Yellow, Timor, Lampung, Bull.

Farming is usually interpreted as a science that learns how a person allocates existing resources effectively and efficiently to gain high returns at a given time. Effective when farmers or producers can allocate resources they possess or are mastered as well and efficiently as the utilization of such resources results in output that exceeds input [4]. The production factor consists of capital, land, and management prowess. Production costs consist of a fixed fee and a fixed fee [5]. Tricomponent Capital as Model ABC attitude. An expressed attitude (affect), B is behavior (behavior), $\mathrm{C}$ is a belief (cognitive) [6].

Based on the background and the problem then the research aims to: (1) identifying the attitude of farmers in Buttu Pamboang village to a decline in the production of local onion; (2) knowing the factors that led to the decline in the production of local onion in Buttu Pamboang Village, Pamboang District, Majene Regency.

\section{Method}

This research is done in Buttu Pamboang, chosen purposively as the location of research. With consideration that the area is the center of the development of local red onion commodity in Majene County. Research is conducted for approximately one month. The population in this research is all farmers who cultivate local onions in the village Buttu Pamboang Pamboang subdistrict of Majene District is ten farmers. Sampling is done using the total purposive sampling method. The samples taken in the study were all populations of 30 local onion farmers.

\section{Results and Discussion}

\subsection{The Attitude of Local Red Onion Farmers}

The attitude of local onion farmers in Buttu Pamboang Village of Pamboang District of Majene Regency against the decline of production is a response or a response of farmer evaluative responders to all forms of attitude i.e., either, good, moderate, less good, or not good. 
Table 1. The attitude of onion farmers to decrease production

\begin{tabular}{|c|c|c|c|c|}
\hline Questions & Weight & Frequency & Score & Percentage (\%) \\
\hline SB & 5 & 2 & 10 & $26.32 \%$ \\
\hline B & 4 & 5 & 20 & $52.63 \%$ \\
\hline$S$ & 3 & 2 & 6 & $15.79 \%$ \\
\hline K & 2 & 1 & 2 & $5.26 \%$ \\
\hline SK & 1 & 0 & 0 & $0 \%$ \\
\hline \multicolumn{2}{|c|}{ To } & 10 & 38 & $100.00 \%$ \\
\hline
\end{tabular}

Source: Primary data after processing (2016)

\subsection{Characteristics Respondent}

Based on the results of the research can be explained that the HR conditions in Golla Kambu business in the village again-AGI Campalagian Sub-district as follows:

\subsubsection{Characteristics Respondents by Age}

Table 2. Average age of local onion farmer

\begin{tabular}{ccc}
\hline Age of Respondents (years) & Number (people) & Percentage (\%) \\
\hline $36-45$ & 5 & 50.00 \\
$46-55$ & 5 & 50.00 \\
\hline Total & 10 & 100.00 \\
\hline
\end{tabular}

Source: Primary data after processing (2016)

In table 2 above mentioned that the average age of respondents aged about 25 - 35 years amounted to 10 people or 33.33 percent, respondents who are $36-45$ years of age amounting to 13 persons or 43.33 percent, while those aged 46 - 55 years numbering 7 persons or 23.34 percent.

\subsubsection{Characteristics of Respondents Based on Education}

Table 3. Average education of local onion farmers

\begin{tabular}{ccc}
\hline Level of Education & Number (People) & Percentage (\%) \\
\hline Elementary school & 4 & 40.00 \\
Junior high school & 3 & 30.00 \\
Senior high school & 2 & 20.00 \\
Bachelor's degree & 1 & 10.00 \\
\hline Total & 10 & 100.00 \\
\hline
\end{tabular}

Source: Primary data after processing (2016)

In table 3, it is seen that farmers in this research area average elementary educated elementary school and senior high school so they do not have special skills that can be relied on to find other jobs, but they only rely on physical. Although there are respondents who do not pursue formal education to high, but they often follow non-formal education i.e., counseling and training in agriculture.

The more often a person follows the counseling, and the training of agriculture will add to the person's insight, especially in developing their farming and acquiring new technological information or innovation. So, although not highly educated but non-formal education can help them add insight into agriculture. 


\subsubsection{Characteristics of Respondents Based on Family Dependents}

Table 4. Dependent family of local red onoin farmers

\begin{tabular}{ccc}
\hline Family Dependents (People) & Number (People) & Percentage (\%) \\
\hline $1-3$ & 3 & 30.00 \\
$4-6$ & 6 & 60.00 \\
$7-9$ & 1 & 10.00 \\
\hline Total & 10 & 100.00
\end{tabular}

Source: Primary data after processing (2016)

In table 4 above, it was seen that the family dependents with intervals of 1-3 people were 3 persons or 30.00 percent, the dependents of $4-6$ people were 6 people or 60.00 percent, while the family dependents of $7-9$ people were 1 person or 10.00 percent. This shows that the farmers of the local onion in Buttu Pamboang village is a relatively high head of the family. So, the cost-of-living costs are high, so the costof-living costs a lot, but the availability of labor originating from within households abounds.

3.2.4. Characteristics of Respondents Based on Farming Experience

Table 5. The farming experience of shallot farmers

\begin{tabular}{ccc}
\hline Farming Experience (Years) & Number (People) & Percentage (\%) \\
\hline $1-5$ & 4 & 40.00 \\
$6-10$ & 6 & 60.00 \\
\hline Total & 10 & 100.00 \\
\hline
\end{tabular}

Source: Primary data after processing (2016)

According to table 5 above, it appears that the respondents had the most experience of local onion farming $6-10$ years with a total of 4 people or 40.00 percent. While the least amount is with a long farming red onion $1-5$ years that is 2 people or 20.00 percent. This suggests that the average respondent has a high experience in the farming of local onion.

\subsubsection{Characteristics of Respondents by Area}

Table 6. The land area of the respondents

\begin{tabular}{ccc}
\hline Land Area (ha) & Number (People) & Percentage (\%) \\
\hline $0.1-0.5$ & 3 & 30.00 \\
$0.6-1.0$ & 5 & 50.00 \\
$1.1-1.5$ & 2 & 20.00 \\
\hline Total & 10 & 100.00 \\
\hline
\end{tabular}

Source: Primary data after processing (2016)

Based on table 6 above it appears that the highest number is $0.6-1.0$ Ha which is 6 people or 60.00 percent, while the lowest amount is farmers who have an area of red onion $0.1-0.5 \mathrm{Ha}$ is 2 people or 20.00 percent. This indicates that the area of local red onion managed by farmers is still narrow. 


\section{Conclusion}

Based on results and discussions, this research can be concluded that:

1. The technology used from the whole entrepreneur is a traditional tool furnace. In the business of local red onion, the use of traditional tools has been very suitable because the use of technology in the production process can affect the flavor. The attitude of onion farmers in Buttu Pamboang Village to the decline in production is well characterized by the desire of the farmers to continue to fix the cause of the decline of production of shallots to obtain maximum results.

2. Factors that affect the decline in red onion production in Buttu Pamboang Village of Pamboang Sub-district is a lack of knowledge of farmers about technical cultivation, a relatively high level of red onion OPT attacks, as well as the influence of climate change.

\section{References}

1. Anoraga P, Djoko S. Koperasi, kewirausahaan, dan usaha kecil. Jakarta: PT Rineka Cipta; 2002. 356 p.

2. Wibowo S. Budidaya bawang. Jakarta: Penebar Swadaya; 2009.

3. Rosatiningrum R. Analisis produksi dan pemasaran usahatani bawang merah (studi kasus Desa Banjaranyar, Kecamatam Brebes, Kabupaten Brebes, Provinsi Jawa Tengah) [bachelor thesis]. Bogor: Institut Pertanian Bogor; 2004.

4. Soekartawi. E-agribisnis: teori dan aplikasinya. In: Seminar Nasional Aplikasi Teknologi Informasi; 2007 Jun 16; Yogyakarta. Jakarta: Journal of Universitas Islam Indonesia; 2007. p. 19-25.

5. Mubyarto. Pengantar ekonomi pertanian. 3rd ed. Jakarta: LP3ES; 2000. 305 p.

6. Sumarwan U. Perilaku konsumen: Teori dan penerapannya dalam pemasaran. 2nd ed. Bogor: Penerbit Ghalia Indonesia; 2011. 468 p. 